DOI 10.23859/2587-8344-2018-2-4-7

УДК 94(47+57)

Егоров Андрей Николаевич

Доктор исторических наук, доцент, Череповецкий государственный университет (Череповец, Россия) anegorov65@mail.ru

Egorov Andrei Doctor of Historical Sciences, Associate Professor, Cherepovets State University (Cherepovets, Russia) anegorov65@mail.ru

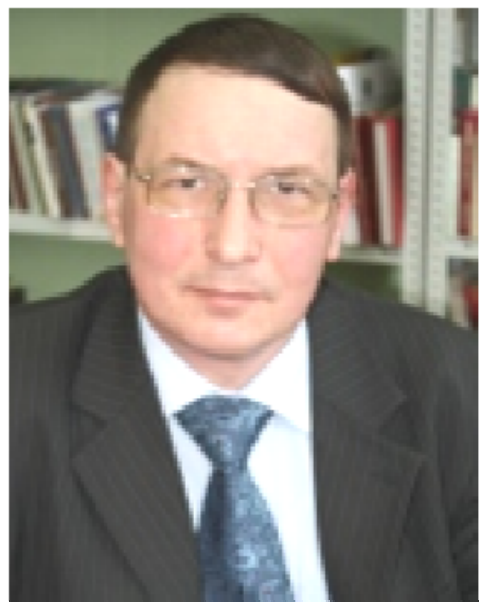

Анти-Рябов русской истории. Рецензия на: Голдин В.И. Человек на фоне войны, или жизнь и судьба лоцмана Бутакова. Архангельск: САФУ, 2017. 201 с.

\title{
Anti-Ryabov of Russian History. Review of: Goldin V.I. A Man against the Background of War, or the Life and Fate of the Marine Pilot Butakov. Arkhangelsk: NArFU, 2017. 201 p.
}

Одним из важнейших направлений современной исторической науки является так называемая «персональная история», или «новая биографическая история», основным предметом исследования которой является «история индивида», восстановление «истории одной жизни». Общая установка историкобиографических исследований заключается не только в реконструкции личной жизни и судеб отдельных индивидов, но и в изучении того исторического со-

Для цитирования: Егоров А.Н. Анти-Рябов русской истории. Рецензия на: Голдин В.И. Человек на фоне войны, или жизнь и судьба лоцмана Бутакова. Архангельск: САФУ, 2017. 201 c. // Historia Provinciae - Журнал региональной истории. 2018. T. 2. № 4. C. 241-250. DOI: 10.23859/2587-8344-2018-2-4-7

For citation: Egorov A. "Anti-Ryabov of Russian history." Review of A Man against the Background of War, or the Life and Fate of the Marine Pilot Butakov, by V.I. Goldin. Arkhangelsk: NArFU, 2017. 201 p. Historia Provinciae - The Journal of Regional History, vol. 2, no. 4 (2018): 241-250, http://doi.org/ 10.23859/2587-8344-2018-2-4-7

(C) Егоров А.Н., 2018

(C) Egorov A., 2018 
циума, в котором они жили и действовали. Именно в этом русле написана вышедшая в 2017 г. в издательстве Северного (Арктического) федерального университета монография В.И. Голдина «Человек на фоне войны, или жизнь и судьба лоцмана Бутакова». В ней на примере и материалах конкретных человеческих судеб раскрываются сложные проблемы революционной эпохи, Гражданской войны и интервенции в России и на Русском Севере, их воздействие на характер и атмосферу последующего развития страны в XX веке.

Главный герой книги - лоцман Степан Иванович Бутаков - не относится к числу хорошо известных персонажей. Его имя связано с драматическими событиями начала иностранной военной интервенции на Русском Севере. Сто лет назад, 1 августа 1918 года эскадра Антанты подошла к острову Мудьюг, защищавшему с моря подступы к городу Архангельску. Подавив героическое сопротивление русских артиллеристов, защищавших Мудьюг, корабли союзной эскадры, пройдя сложнейшим фарватером Северной Двины, что не могли бы сделать без посторонней помощи, достигли Архангельска и высадили войска в городе, где одновременно началось антисоветское восстание, приуроченное к приходу интервентов. Так началась интервенция стран Антанты в Архангельск, послужившая толчком к широкомасштабной Гражданской войне на Севере России, обернувшейся для северян тяжелейшими последствиями, драмами и потерями, подробно рассмотренными в рецензируемой монографии. Человеком, который провел эскадру интервентов в Архангельск, длительное время считался председатель Архангельского общества лоцманов С.И. Бутаков. После долгих розысков его нашли и арестовали чекисты в 1927 г. В ноябре того же года в Архангельске состоялся суд над ним и несколькими его ближайшими родственниками. Бутакова признали виновным и приговорили к расстрелу, а в 1992 г. посмертно реабилитировали.

Биография С.И. Бутакова вместе с историей проводки кораблей Антанты в Архангельск и стали предметом исследования в книге известного историка В.И. Голдина. Еще в конце 80-х годов XX века он приступил к фундаментальной научной разработке истории интервенции и антибольшевистского движения на Русском Севере. По этой теме он защитил докторскую диссертацию, подготовил ряд монографий, публикаций документов и большое количество статей. Еще в конце 1980-х гг., изучая следственные дела участников антибольшевистского движения, В.И. Голдин ознакомился в архиве Управления КГБ по Архангельской области с делом С.И. Бутакова и заинтересовался драматической судьбой этого человека. В дальнейшем, разрабатывая историю Гражданской войны на Русском Севере, Голдин много писал о судьбах конкретных людей, воссоздавал их жизненный путь, часто очень драматический или даже трагический. Столетие Российской революции 1917 г. и Гра- 
жданской войны стимулировало появление новых научных проектов, одним из которых и стала монография об архангельском лоцмане.

Важнейшими материалами для любой историко-биографической работы являются источники личного происхождения: мемуары, дневники, письма главных героев. С.И. Бутаков не вел дневников, по понятным причинам (был расстрелян) не написал мемуаров, но все же отдельные нарративные источники от него сохранились. Это письма 1920-х гг. к родным и показания, данные в ходе следствия и суда. Именно эти материалы позволили В.И. Голдину реконструировать, насколько это возможно, внутренний мир своего героя. Монография основана на большом количестве разнообразных источников. Помимо обширного следственного дела С.И. Бутакова привлечены и другие следственные дела архангельских лоцманов из Архива Регионального управления ФСБ по Архангельской области, а также разнообразные архивные материалы, извлеченные более чем из двадцати архивов страны, документальные издания, справочная, энциклопедическая и мемуарная литература, электронные ресурсы. В частности, использован сценарий документального фильма «Штрихи семейной биографии», подготовленного по заказу и при участии Л.Б. Бровиной, внучки С.И. Бутакова, а также материалы бесед с ней и другими его потомками, и некоторые предоставленные ими документы (в том числе послужные списки С.И. Бутакова).

Монография выстроена в хронологическом ключе - в ней последовательно рассматриваются вехи жизненного пути главного героя: жизнь и работа в Архангельске, где он прошел путь от штурмана дальнего плавания до председателя Архангельского общества лоцманов, его роль в событиях интервенции и Гражданской войны на Русском Севере, эмиграция в Норвегию, пребывание в Крыму в 1920-1921 гг., жизнь на Дальнем Востоке, куда С.И. Бутаков уехал от возможных преследований, и, наконец, арест, следствие и суд. Наибольшее внимание уделяется периоду Гражданской войны и иностранной военной интервенции.

Центральный раздел монографии посвящен началу интервенции в Архангельск и роли в этом С.И. Бутакова. Летом 1918 года он, являясь председателем Архангельского общества лоцманов, неожиданно отправился из Архангельска в Мурманск, оккупированный в это время интервентами Антанты, и передал там письмо английскому консулу от антисоветской монархической организации «Белый крест», к которой, возможно, сам не принадлежал (передать письмо его попросил близкий сослуживец). В Мурманске Бутаков согласился сотрудничать с интервентами, что было для них настоящим подарком. Для того чтобы попасть в Архангельск, нужно пройти сложным фарватером Северной Двины, что невозможно без лоцманской проводки. Вряд ли интервенты могли найти человека лучше, чем Бутаков, который возглавлял организацию архан- 
гельских лоцманов. Прибыв вместе с эскадрой Антанты в Архангельск, Бутаков сыграл неприглядную роль анти-Рябова русской истории ${ }^{1}$. Подробно рассмотрев этот сюжет, В.И. Голдин пришел к выводу, что непосредственной проводкой судов Бутаков не занимался - эту работы выполнили 8 лоцманов, захваченных интервентами в плен на Северо-Двинском маяке. Тем не менее, во время экспедиции Бутаков находился на военном корабле «Найрана», неоднократно вызывался на капитанский мостик в критические минуты и отвечал на вопросы контр-адмирала Т.У. Кемпа. Такое поведение вполне можно охарактеризовать терминами «сотрудничество с интервентами», «помощь интервентам».

Реконструируя взгляды своего героя, В.И. Голдин стремится дать ответ на важнейший вопрос: что же побудило С.И. Бутакова, как и многих других русских людей, сотрудничать с интервентами. Как показывает Голдин, мотивация Бутакова была обусловлена его антибольшевистскими взглядами, неприятием идей и практики советской власти. Архангельский лоцман полагал, что необходимо обратиться к союзникам, чтобы помочь им или во взаимодействии с ними свергнуть советскую власть и попытаться организовать новую жизнь на Севере. Он надеялся решить в сотрудничестве с представителями Антанты вопросы, которые стояли здесь на повестке дня, получить от них продовольствие и необходимую помощь в налаживании новой жизни и в борьбе с большевиками. К этому добавлялось чувство протеста против унизительного Брестского мира, заключенного большевиками. Кроме того, подчеркивает Голдин, Бутаков в годы Первой мировой войны по роду службы поддерживал тесные отношения с англичанами, обеспечивал проводку судов Антанты, и они оставались для него союзниками России. Подобной точки зрения придерживались многие бывшие русские офицеры и гражданские лица, находившиеся в Архангельске, на Севере и в России в целом в тот период.

Рассмотрев реальную политику интервентов на Русском Севере, В.И. Голдин показал, как постепенно пропадали иллюзии таких людей как С.И. Бутаков о бескорыстной помощи союзников по Антанте. Так, с первых же дней после захвата Архангельска обнаружились глубокие разногласия между командованием интервентов и Верховным управлением Северной области. Несмотря на заявленные претензии членов ВУСО на верховенство и приоритет своей власти, генерал Ф. Пуль не доверял им и не собирался всерьез считаться с ними. Обобщая ситуацию, складывавшуюся в Северной области, Голдин подчеркивает, что генерал Пуль взял в свои руки руководство ключевыми

${ }^{1}$ Во время Северной войны в 1701 г. поморский кормщик Иван Рябов был захвачен в плен шведами и доставлен на борт шведской эскадры, следовавшей к Архангельску, чтобы захватить Новодвинскую крепость, прикрывавшую подступы к городу. Но Рябов вместо помощи иностранным захватчикам посадил два их судна на мель перед пушками крепости, и они были уничтожены; шведская экспедиция в Архангельск была сорвана. 
сферами ее жизни и, верный своей колониальной выучке, вел себя весьма бесцеремонно в отношении Верховного управления, мало считаясь с ним и его членами. Командующий войсками (с ноября 1918 по август 1919 г.) и член правительства Северной области генерал В.В. Марушевский впоследствии, уже в эмиграции, так размышлял о взаимоотношениях с иностранными союзниками: «Несмотря на ряд заявлений всего дипломатического корпуса о невмешательстве во внутренние дела области, фактически вся политика области была в тисках иностранного представительства, при явном перевесе даже в мелочах английского влияния... Чтобы охарактеризовать создавшееся положение, проще всего считать его «оккупацией» ${ }^{2}$.

Биография С.И. Бутакова написана в строго объективном ключе - автор не стремится осудить или оправдать своего героя, оставляя читателям право самим судить о сложности нравственного выбора, который приходилось делать людям в годы Гражданской войны. Бутаков сделал ставку на интервентов, а красные защитники острова Мудьюг 1 августа 1918 г. приняли неравный бой с ними (8 орудий против 70), героически сражались более двух часов, а затем взорвали погреба с боезапасом, сняли орудийные замки и организованно отступили. Бутаков наблюдал этот бой с борта «Найраны». Так, одни русские люди защищали свою родину под флагом мировой революции, а другие помогали интервентам под лозунгами «Единой и неделимой России». В наши дни идет немало дискуссий об итогах, последствиях, исторических уроках Гражданской войны в России и их значении для современности. Как считает В.И. Голдин, один из уроков заключается в том, что не следует во внутриполитической борьбе прибегать к помощи зарубежных «союзников». Иностранная военная интервенция в России и на Русском Севере «в полной мере показала, что подобные «союзники» стремятся реализовать главным образом собственные геополитические, экономические и иные цели за счет ослабления той страны, в дела которой вмешиваются, и это действительно актуально для наших дней и будущего» ${ }^{3}$.

В монографии, наряду с самим главным героем, много и других действующих лиц: его родные и близкие, сослуживцы, лидеры и участники антибольшевистского движения и интервенции в России и в Северной области, их противники из советского лагеря и др. Для более глубокого понимания событий и судеб людей дается подробное биографическое приложение к книге. Безусловно, данная монография является достойным примером работы в историко-биографическом жанре, а вводимый в научный оборот фактический

${ }^{2}$ Цит. по: Голдин В.И. Человек на фоне войны, или жизнь и судьба лоцмана Бутакова. Архангельск: САФУ, 2017. С. 73.

${ }^{3}$ Там же. С. 154. 
материал станет существенным подспорьем для всех историков, изучающих переломные страницы российской истории.

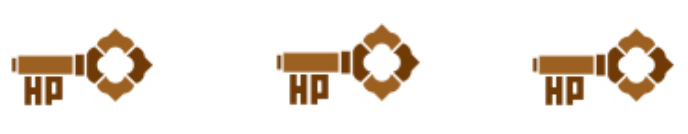

One of the most important trends in modern historical science is the so-called personal history, or a new biographical history, where the main subject matter is related to the individual history - reconstruction of a person's life story. The general orientation of historical and biographical study would not only reconstruct personal lives and individual destinies, but also study the historical society where those people lived and acted. The monograph 'A man against the background of war, or the life and fate of the marine pilot Butakov' by V.I. Goldin published in 2017 by the publishing house of the Northern (Arctic) Federal University is written in line with this. It uses the example and materials of specific persons' destinies to reveal the complex problems of the revolutionary era, the Civil War and the intervention in Russia and in Northern Russia, and their impact on the nature and atmosphere of the country's subsequent development in the $20^{\text {th }}$ century.

The protagonist of the book - the marine pilot Stepan Ivanovich Butakov - is not amongst the well-known characters. His name relates to the dramatic events of the beginning of foreign military intervention in Northern Russia. A hundred years ago, on $1^{\text {st }}$ August 1918, the Entente squadron approached the island of Mudyug, which defended the approaches to the city of Arkhangelsk from the sea. Having suppressed the heroic resistance of Russian artillerymen defending Mudyug, the ships of the allied squadron, having passed through the most complicated navigational channel of the Northern Dvina - which could not have been done without any help - reached Arkhangelsk and landed troops in the city where an anti-Soviet uprising started which was timed to coincide with the arrival of the invaders. This was the beginning of the Allied intervention in Arkhangelsk, which served as an impetus to the large-scale Civil War in the north of Russia, which carried severe consequences for the northerners, where dramas and losses were considered in detail in the reviewed monograph. They believed for a long time that the man who led the squadron of the invaders to Arkhangelsk was the chairman of the Arkhangelsk society of marine pilots S.I. Butakov. After a long search, the Chekists (public security officials) found and arrested him in 1927. His trial and that of several of his closest relatives was held in Arkhangelsk in November of the same year. Butakov was found guilty and sentenced to death, and in 1992 was rehabilitated posthumously. 
The biography of S.I. Butakov together with the history of guiding the Entente ships to Arkhangelsk became the subject of research in the book of the famous historian V.I. Goldin. As early as in the end of the 1980s, he started his fundamental scientific research work dedicated to the history of intervention and the anti-Bolshevik movement in Northern Russia. He defended his doctoral dissertation on this topic, prepared several monographs, published documents and many articles. Back in the late 1980s, whilst studying the investigation cases of participants in the antiBolshevik movement, V.I. Goldin familiarized himself with the case of S.I. Butakov in the archive of the Committee for State Security (KGB) Directorate in the Arkhangelsk region and became interested in the dramatic fate of this man. Later, whilst studying further the history of the Civil War in Northern Russia, Goldin wrote a lot about the fate of specific people, recreated the details of their life journey, often very dramatic or even tragic ones. The centenary of the Russian Revolution of 1917 and the Civil War gave an impetus to the origin of new scientific projects, and the monograph on the Arkhangelsk marine pilot was one of them.

The most important materials for any historical and biographical work would be the sources of personal origin: memoirs, diaries and the correspondence between the main characters. S.I. Butakov did not keep any diaries, did not write any memoirs for obvious reasons (he was shot dead), nevertheless, several of his narratives were preserved as sources. These are his letters from the 1920s to the relatives and his testimony given during the investigation and the trial. These materials allowed V.I. Goldin reconstruct, as far as possible, the inner world of his character. The monograph is based on many various sources. In addition to the extensive investigative case of S.I. Butakov, the author appealed to other investigative cases of Arkhangelsk marine pilots from the Archive of the Regional Directorate of the Federal Security Service in the Arkhangelsk region, as well as extracted various archival materials from more than twenty archives of the country, documentary publications, reference and encyclopedic sources, memoirs and electronic resources. He used the scenario of the documentary film 'Sketches of family legacies' prepared on order and with participation of L.B. Brovina, the grand-daughter of S.I. Butakov, as well as the interviews with her and Butakov's other descendants, and some of the documents they provided (including the service records of S.I. Butakov).

The monograph is arranged chronologically: it consistently examines the milestones of the protagonist's life path: his life and work in Arkhangelsk, where he travelled a long way from being a navigator of a long voyage to the chairman of Arkhangelsk society of marine pilots; his role in the intervention events and the Civil War in Northern Russia; emigration to Norway; residency in the Crimea in 1920-21; his life in the Far East, where S.I. Butakov left trying to escape from imminent persecution, and, finally, the arrest, investigation and trial. The greatest attention is paid to the period of the Civil War and foreign military intervention. 
The central section of the monograph is devoted to the beginning of the intervention in Arkhangelsk and the role of S.I. Butakov in this matter. In the summer of 1918, as chairman of Arkhangelsk society of marine pilots, he unexpectedly left Arkhangelsk for Murmansk occupied at that time by the Entente invaders and delivered there a letter to the British consul from the anti-Soviet monarchist organization White Cross, to which he himself probably did not belong (he was asked to pass the letter by a close colleague). In Murmansk, Butakov agreed to cooperate with the invaders, which was a real 'gift' for them. To get to Arkhangelsk, one needed to go through the complicated navigational channel of the Northern Dvina, and this was impossible without pilotage. It is unlikely that the invaders could find a better person than Butakov, who headed the Arkhangelsk marine pilots' organization. Arriving with the Entente squadron to Arkhangelsk, Butakov played the unsavory role of anti-Ryabov of Russian history ${ }^{1}$. Having considered this subject in detail, V.I. Goldin concluded that Butakov did not pilot the ships directly: this work was carried out by eight pilots captured by the invaders at the Severo-Dvinsky lighthouse. Nevertheless, during the expedition, Butakov was on HMS Nairana, was repeatedly called to the captain's bridge at critical moments and answered the questions of rear-admiral Thomas Camp. Such behavior can be fully characterized by the terms of 'cooperation with invaders' and 'assistance to invaders'.

Reconstructing the views of his protagonist, V.I. Goldin strives to answer the most important question: what motivated S.I. Butakov, like many other Russian people, to cooperate with the invaders. Goldin shows that Butakov's motivation was based on his anti-Bolshevik views and rejection of the ideas and practices of Soviet power. The Arkhangelsk pilot believed that it was necessary to turn to the allies to help them, or in cooperation with them, to overthrow the Soviet power and try to arrange a new life in the North. He hoped to solve the issues that were put on the agenda in cooperation with the Entente representatives, to obtain food and the required help from them in establishing the new life and whilst fighting the Bolsheviks. A sense of protest the humiliating Brest peace concluded by the Bolsheviks was added to this. In addition, as Goldin emphasizes, Butakov during the First World War, maintained a close relationship with the British by the nature of service, provided the piloting of the Entente ships, and they remained his allies for Russia. This view was shared by many former Russian officers and civilians who were in Arkhangelsk, in the North and in Russia on the a whole, during that period.

${ }^{1}$ During the Great Northern War in 1701, the pomor (coast-dweller) helmsman Ivan Ryabov was captured by the Swedes and brought on board of the Swedish squadron headed to Arkhangelsk to seize the Novodvinskaya fortress, which protected the approaches to the city. However, Ryabov, instead of helping the foreign invaders, ran their two ships aground in front of the guns in the fortress, and they were destroyed. The Swedish expedition to Arkhangelsk was disrupted. 
Having considered the real policy of the invaders in Northern Russia, V.I. Goldin showed how the illusions and doubt of such people as S.I. Butakov regarding the disinterested assistance of the Allies in the Entente were dispelled gradually. Thus, from the very first days following the seizure of Arkhangelsk, deep disagreements were observed between the command of the invaders and Russia Supreme Administration of the Northern Region. Despite the claims of the WUAS members regarding the supremacy and priority of their power, Major General Sir Frederick Poole did not trust them and did not intend to consider them seriously. Summarizing the situation in the Northern Region, Goldin emphasizes that General Frederick Poole took control of the key spheres of the region's life and, true to his colonial training, behaved very unceremoniously towards the Supreme Administration, taking little account of it and its members. The commander of the troops (from November 1918 to August 1919) and a member of the Northern region's government General V.V. Marushevsky later, whilst already in emigration, reflected upon the relations with the foreign allies as follows: "Despite a number of statements by the entire diplomatic corps regarding non-interference in the internal affairs of the region, in fact, the whole policy of the region was in the grip of a foreign mission, with a clear advantage even in the smallest details of English influence... To characterize the situation, the easiest way is to consider it "occupation","

The biography of S.I. Butakov is written in a strictly objective manner: the author does not strive to condemn or justify his protagonist, leaving it for the readers themselves to judge the complexity of the moral choices that had to be made by the people during the Civil War. Butakov made a bid for the invaders, and the Reds - defenders of Mudyug Island on $1^{\text {st }}$ August 1918 were dragged into an unequal battle with them (eight guns against 70), heroically fought for more than two hours, and then blew up the cellars with ammunition, removed the gun locks and withdrew in an orderly manner. Butakov watched this battle from aboard Nairana. Thus, some Russian people defended their homeland under the banner of the world revolution, whilst others helped the invaders under the slogans of 'Great Russia, United and Indivisible'. Nowadays, there is a lot of discussion about the results, the consequences and historical lessons of the Civil War in Russia and their significance for the present times. According to V.I. Goldin, one of the lessons is that one should not resort to the help of foreign 'allies' in the internal political struggle. The foreign military intervention in Russia and Northern Russia "fully demonstrated that such 'allies' mainly strive to accomplish their own geopolitical, economic and other purposes at the expense of weakening the country in the affairs in which they interfere, and this is very relevant for our days and the future",3.

${ }^{2}$ Cit. ex: V.I. Goldin, A man against the background of war, or the life and fate of the marine pilot Butakov (Arkhangelsk: NArFU, 2017), 73.

${ }^{3}$ Op. cit., 154. 
In the monograph, along with the protagonist himself, there are many other characters: his family and friends, co-workers, leaders and participants of the antiBolshevik movement and intervention in Russia and the Northern region, their opponents from the Soviet camp, etc. To understand the events and people's destinies deeper, the book contains a detailed biographical appendix. Undoubtedly, this monograph is a worthy example of work in the historical and biographical genre, and the factual material put into scientific circulation will become an essential aid for all historians studying the life-changing chapters of Russian history. 